\title{
Neo-Marxian social class inequalities in self-rated health among the employed in South Korea: the role of material, behavioral, psychosocial, and workplace environmental factors
}

\author{
Kyoung Ae Kong ${ }^{1}$, Young-Ho Khang ${ }^{2}$, Hong-Jun $\mathrm{Cho}^{3}$, Sung-Mi Jang ${ }^{4}$ and Kyunghee Jung-Choi ${ }^{4^{*}}$ (D)
}

\begin{abstract}
Background: The aim of this study was to examine the pattern of social inequality in self-rated health among the employed using the Wright's social class location indicator, and to assess the roles of material, behavioral, psychosocial, and workplace environmental factors as mediating factors in explaining the social class inequality in selfrated health in South Korea.

Methods: This study used data from the 4th Korea National Health and Nutrition Examination Survey from 2007 to 2009. Study subjects included the employed population of 4392 men and 3309 women aged 19-64 years. Subjects were classified into twelve social class positions based on the Wright's social class map. The health outcome was self-rated health. Material, psychosocial, behavioral, and workplace environmental factors were considered as potential mediators in explaining social class health inequality. We calculated prevalence ratios of poor self-rated health according to social class, adjusted for age and mediating factors using Poisson regression models.

Results: Nonskilled workers and petty bourgeoisie reported worse self-rated health than other social classes among men. The age-adjusted prevalence of petty bourgeoisie and nonskilled workers were about four-fold greater than that of managers. Expert supervisors in the contradictory class location had a greater prevalence of poor self-rated health than experts in men. In women, the prevalence of poor self-rated health was greater in most social classes than their male counterparts, while the differences among social classes within women were not statistically significant. Workplace environmental factors explained the social class inequality by from 24 to $31 \%$ in nonskilled and skilled workers and nonskilled supervisors, respectively, and material factors showed an explanatory ability of about 8\% for both nonskilled workers and petty bourgeoisie in men.
\end{abstract}

Conclusions: We showed the inequality in self-rated health according to the Wright's social class in an industrialized Asian country. Policy efforts to improve workplace environments in nonskilled and skilled workers and nonskilled supervisors would have a moderate effect on reducing the magnitude of social class inequality in self-rated health. Furthermore, the means to improve power relations in the workplace should be devised to further reduce the social class inequalities in health.

Keywords: Social class, Neo-Marxist, Self-rated health, Inequality in health, Mediating factors

\footnotetext{
* Correspondence: jungchoikh@gmail.com

${ }^{4}$ Department of Occupational and Environmental Medicine, Ewha Womans University School of Medicine, Seoul, Korea

Full list of author information is available at the end of the article
} 


\section{Background}

Health inequality by socioeconomic position (SEP) is ubiquitous. Studies have reported socioeconomic health inequality using various socioeconomic position indicators [1-7]. Education, occupation, and income have been used most frequently as SEP indicators, whereas relatively few studies introduced the social class based on Neo-Marxist theory [8, 9]. However, health inequality analyses employing the Neo-Marxian approach may reveal the mechanisms of inequality through social relations of control over productive assets in capitalist societies, which cannot be captured with approaches using conventional SEP indicators [9-11].

The Wright's class location, one of Neo-Marxian class indicators, represents power relations generating in the point of production [12]. First, those having productive assets have control over the means of production and labor force. Non-owners are exploited through the production process and it affects the distribution of income and working condition. Second, employers can delegate part of their authority to managers or supervisors. Managers and supervisors with organizational assets dominate workers using surveillance or sanctions. However, because they simultaneously belong to non-owners, they are named as a contradictory class. Third, employees are differentiated by their skill assets. Employees with high levels of skills can have the advantage within exploitation relations. In this respect, Neo-Marxian class analysis implicates the mechanism generating class inequality and can reveal different aspects of social inequality in health, which have not been explored using traditional measures of SEP $[8,9,13]$.

Meanwhile, explaining the roles of the potential mediating factors between SEP and health outcome is important for policy implications. When it comes to NeoMarxian social class, the studies exploring mediating factors have been also relatively sparse, except for a few examples [14-16]. In addition, except for a few studies using Japanese samples $[17,18]$, investigations into the relationship between Neo-Marxian social class and health outcomes have rarely been performed in Asian capitalist countries. South Korea, one of OECD countries, underwent rapid industrialization after the Korean War in 1950-1953, as a result of which the capitalist class and the proletariat have grown and differentiated $[19,20]$. This circumstance could provide the suitable data for investigating the relationship between NeoMarxian social class and health.

A simplified conceptual framework (Fig. 1) [21] suggests four potential mediating factors explaining social class inequality in self-rated health: material [22], behavioral [23], psychosocial [22], and workplace environmental factors [14, 24]. We hypothesized that the inequality in poor self-rated health, according to Wright's social

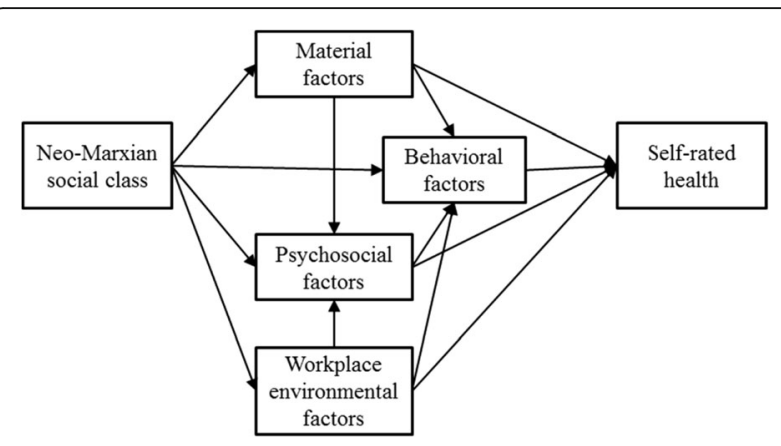

Fig. 1 Conceptual framework for explaining social class inequality in self-rated health

class indicators, would be evident in South Korea. In addition, we predicted the more important roles of material and workplace environmental factors in explaining the social class inequality. Therefore, the aim of this study was to examine the pattern of socioeconomic inequality in self-rated health using Wright's social class location indicator among the employed, and to estimate the roles of material, behavioral, psychosocial, and workplace environmental factors as mediating factors in explaining the social class inequality in self-rated health, using South Korean national samples.

\section{Methods}

\section{Data and study subjects}

This study was based on data obtained from the 4th Korea National Health and Nutrition Examination Survey (KNHANES), which was conducted in 20072009 by the Korea Centers for Disease Control and Prevention [25]. The survey used a stratified multistage probability sampling design to select about 13,800 households as a representative sample of the civilian, noninstitutionalized South Korean population. Among a total of 24,871 participants in the 4th KNHANES, this study was limited to the employed population aged 19-64 years (4392 men and 3309 women), who were employees or self-employed. Unpaid family workers were not included.

\section{Social class, health status, and potential mediating variables \\ Social class variables}

Subjects were classified into twelve social class positions by the three dimensions based on the Erik Olin Wright's social class map (Fig. 2) [12], using survey questions. In the property dimension representing the relation to means of production, the respondents were classified according to whether they were self-employed. Respondents who were self-employed were classified as property owners. There were three categories of owners: capitalists, small employers, and petty bourgeoisie. 
Relation to means of production

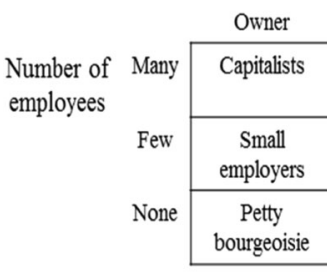

\begin{tabular}{|c|c|c|c|c|}
\hline \multicolumn{3}{|c|}{ Employee } & \multirow{3}{*}{$\begin{array}{l}\text { Managers } \\
\text { Supervisors }\end{array}$} & \multirow{3}{*}{$\begin{array}{c}\text { Relation } \\
\text { to } \\
\text { authority }\end{array}$} \\
\hline $\begin{array}{l}\text { Expert } \\
\text { managers }\end{array}$ & $\begin{array}{l}\text { Skilled } \\
\text { managers }\end{array}$ & $\begin{array}{c}\text { Nonskilled } \\
\text { managers }\end{array}$ & & \\
\hline $\begin{array}{c}\text { Expert } \\
\text { supervisors }\end{array}$ & $\begin{array}{c}\text { Skilled } \\
\text { supervisors }\end{array}$ & $\begin{array}{l}\text { Nonskilled } \\
\text { supervisors }\end{array}$ & & \\
\hline Experts & $\begin{array}{l}\text { Skilled } \\
\text { workers }\end{array}$ & $\begin{array}{c}\text { Nonskilled } \\
\text { workers }\end{array}$ & $\begin{array}{c}\text { Non- } \\
\text { management }\end{array}$ & \\
\hline Experts & Skilled & Nonskilled & & \\
\hline
\end{tabular}

Fig. 2 Erik Olin Wright's class typology [12]

Respondents who employed 10 or more workers (excluding unpaid family members) were classified as capitalists. The self-employed with 1-9 workers were classified as small employers, and those who did not hire any workers other than unpaid family member workers were classified as petty bourgeoisie.

Employees were classified into nine class positions by the combination of two dimensions - the organizational dimension (i.e., authority) and the skill dimension, each with three categories. The organizational dimension was determined by whether or not he/she had a position supervising the other workers in the workplace and by his/her occupation according to the Korean Standard Classification of Occupation (KSCO). The respondents who had a position supervising the other workers and whose occupations based on KSCO were managers were classified as managers in the organizational dimension. The respondents who had a position supervising the other workers and had occupations other than managers were classified as supervisors. Those who did not have the power of control were classified as workers.

The skill dimension was determined by occupation according to KSCO and educational level. The respondents who had completed a college education and were managers or professionals in their occupation were classified as experts. Managers or professionals with educational attainments of high school graduate or less, and clerical workers or craft and related trades workers who had completed a college education were classified as the skilled. The employees who were not assigned to the expert or skilled categories were classified as the nonskilled.

In this study, we finally used ten groups of class positions: capitalists, small employers, petty bourgeoisie, managers, expert supervisors, skilled supervisors, nonskilled supervisors, experts, skilled workers, and nonskilled workers. There was no person in the nonskilled managers group. The expert managers and the skilled managers were pooled into the managers group due to the small number of individuals.

\section{Health status variables}

A few studies employed self-rated health as an outcome measure in the association with Neo-Marxian social class $[4,14,26,27]$. We used the question about selfrated health status: "In general, would you say that your health is: very good, good, moderate, poor, or very poor?". Then self-rated health was categorized into the dichotomous outcome of poor (poor and very poor) and good health status (moderate or better). Prior South Korean studies showed increased mortality risks for those who reported their health as poor or very poor while no significant mortality differences were detected among those who reported their health status as moderate, good, and very good [28, 29].

\section{Potential mediating variables}

Material, behavioral, psychosocial, and workplace environmental factors were chosen as potential mediating variables in the association between social class and health status. Material factors were home ownership (no or one home, two or more home) and household income. Income was divided into low, middle low, middle high, and high groups using sex- and age-specific quartiles of the monthly equivalent household income.

Behavioral factors included smoking (current smokers, former smokers, and never smokers), alcohol use, and physical inactivity. Alcohol use was divided, using drinking frequency and amount over the last year, into never or nearly never drinkers (less than once per month), moderate drinkers (once per month or more, but less than the amount of high-risk drinkers), high-risk drinkers (on average, twice per week or more and on one occasion, 7 or more drinks per week in men or 5 or more drinks in women). Engagement in physical activity was defined as engaging in moderate activity for more than $30 \mathrm{~min}$ on 5 days per week or intense activity for more than 20 min for 3 days per week, while no engagement in physical activity was defined as having less than the level of physical activity defined above.

Psychosocial factors included the feeling of depression and the perceived level of stress. The feeling of 
depression was defined based on a yes or no question about the feeling of sadness or despair that lasted for at least 2 weeks during the last year. A single question with four response levels was used to ascertain perceived stress level. The answer was categorized into low (nearly none and low) and high (high and very high) groups.

Workplace environmental factors were based on the subjective interpretation on the physical workplace environment and the psychological workplace environment. The physical workplace environmental factor was obtained from four questions using the 4-point Likert scale: cleanliness of workplace, risk of workplace accidents, work in uncomfortable positions for a long time period, and workload for moving heavy loads. The psychological workplace environment was evaluated with two questions using the 4-point Likert scale: job burden and decision latitude. The four categories of the physical and psychological workplace environments were created according to the quartiles of the sum score in the corresponding questions.

\section{Statistical analysis}

Age-standardized rates of poor self-rated health by gender were calculated by the direct method with the 2005 Korean census population being the referent. We calculated the prevalence ratio (PR) for social class adjusted for age using Poisson regression models with the robust variance [30]. As the reference category, we chose the managers class position in men considering the lowest prevalence of poor self-rated health in the group, while we used the expert supervisors in women as the reference group due to the lower poor health prevalence in the group and the insufficient number of managers.

A baseline model and additional five models were created to assess the role of each potential mediating or all potential mediating variables in explaining the association between social class and poor self-rated health. The explanatory power, that is, the degree to which the potential mediating variable explains the relationship of social class with health, was determined by the percentage change in PR, when the potential mediating variables were added to the baseline model $(100 \times[(P R$ in the baseline model) - (PR in the model adjusted for potential mediating variables)]/[(PR in the baseline model) - 1]). This method has been used to assess the contributing roles of potential mediating variables in socioeconomic inequality in health [21, 23, 31-34]. We assumed here that the roles of exposure-outcome confounders and potential mediator-outcome exposure would be minimal [35]. We presented the result of regression models only in men, because all the differences in selfrated health by social classes in women were not statistically significant. All analyses were performed using SAS statistical software (version 9.2, SAS institute, Cary, NC).

\section{Results}

Table 1 shows the distribution of the study subjects and the prevalence of the poor self-rated health status according to social class. Among both men and women, the social class position with the largest number of subjects was nonskilled workers $(24.6 \%$ in men and $41.0 \%$ in women) and the next largest social class position was petty bourgeoisie ( $22.3 \%$ in men and $20.7 \%$ in women). Capitalists (2.6\% in men and $0.5 \%$ in women) and managers $(2.7 \%$ in men and $0.4 \%$ in women) were those with the smallest number of subjects. In men, small employers, petty bourgeoisie, expert and nonskilled supervisors, and skilled and nonskilled workers had a significantly greater prevalence of poor self-rated health compared with managers. Especially, the age-adjusted prevalence of petty bourgeoisie and nonskilled workers were about four-fold greater than the prevalence of managers (PR 3.97 and 3.78, respectively). Capitalists, skilled supervisors and experts had PRs ranging between 1.85 and 2.34, but they were not statistically significant. For women, the prevalence of poor self-rated health was greater in most social classes than male counterparts, but the differences among social classes within women were not statistically significant.

Table 2 presents the distribution of poor self-rated health by potential mediating variables in men. Low household income was related to poor self-rated health, as were feeling depressed, perceived high stress level, and poor workplace environment (Cochran-MantelHaenszel test, all $p$ values $<0.05)$. Never or nearly never drinkers as well as high risk drinkers were more likely to report poor health compared with moderate drinkers. Smoking was also associated with poor self-rated health, although the Cochran-MantelHaenszel test showed a marginal significance. The proportions of current smoker or high risk drinker were smaller in women than men, while the prevalences of women feeling depressed or with a very bad psychosocial work environment were greater in women than men. The association between potential mediating variables and poor self-rated health was all statistically significant in women (Additional file 1: Table S1).

Table 3 shows the distribution of potential mediating variables according to social class in men. More than $50 \%$ of capitalists belonged to the high income quartile group while over $50 \%$ of petty bourgeoisie, nonskilled supervisors, and nonskilled workers belonged to low and middle low income quartile groups. The proportion of current smokers was over $50 \%$ in capitalists, small employers, nonskilled supervisors, skilled workers and nonskilled workers. The proportion of high risk drinkers was higher in managers, capitalists, and small employers than other social class positions, while the proportion of 


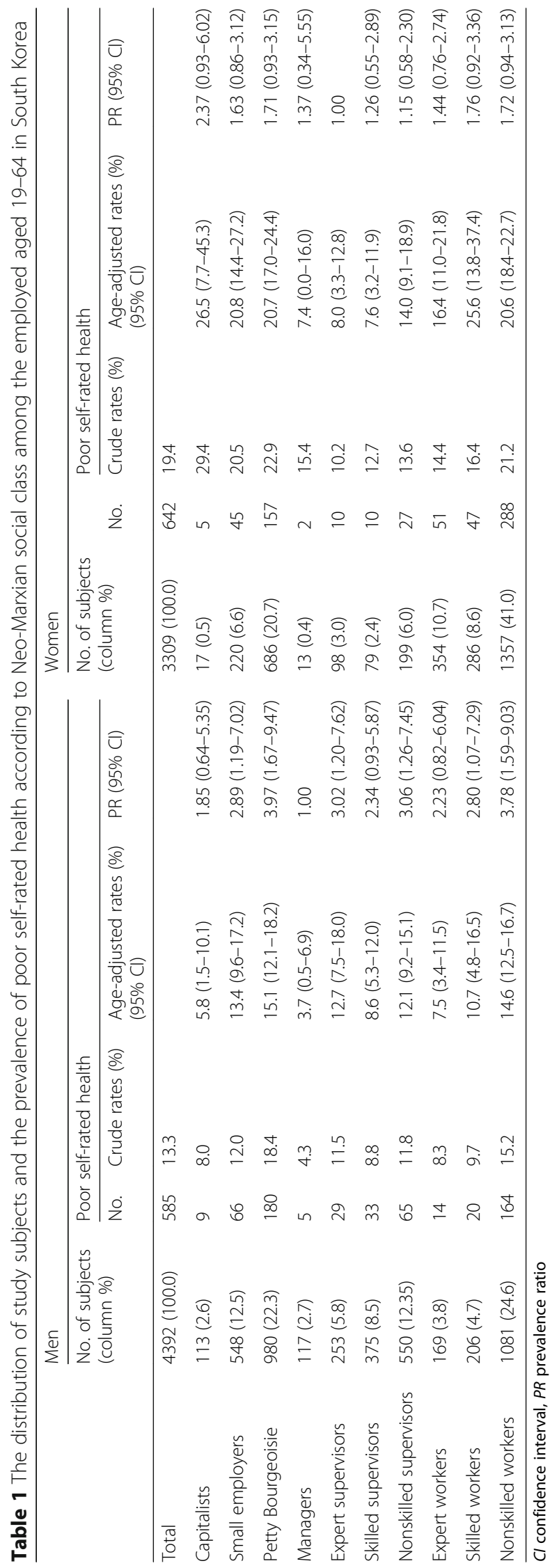


Table 2 The distribution of study subjects and the prevalence of poor self-rated health according to potential mediating variables among South Korean employed men aged 19-64

\begin{tabular}{|c|c|c|c|c|c|}
\hline & & & $\begin{array}{l}\text { No. (column \%) of } \\
\text { subjects }\end{array}$ & $\begin{array}{l}\text { No. (\%) of poor } \\
\text { self-rated health }\end{array}$ & $P$ value \\
\hline Total & & & $4392(100.0)$ & $585(13.3)$ & \\
\hline \multirow[t]{6}{*}{ Material factors } & \multirow[t]{4}{*}{ Income } & Low & $969(22.1)$ & $152(15.7)$ & \multirow[t]{4}{*}{0.004} \\
\hline & & Middle low & $1089(24.8)$ & $151(13.9)$ & \\
\hline & & Middle high & $1156(26.3)$ & $156(13.5)$ & \\
\hline & & High & $1178(26.8)$ & $126(10.7)$ & \\
\hline & \multirow[t]{2}{*}{ House ownership } & $0-1$ house & $3930(89.5)$ & $529(13.5)$ & \multirow[t]{2}{*}{0.098} \\
\hline & & $\geq 2$ houses & $462(10.5)$ & $56(12.1)$ & \\
\hline \multirow[t]{8}{*}{ Health behavioral factors } & \multirow[t]{3}{*}{ Smoking } & Never & $776(17.7)$ & $90(11.6)$ & \multirow[t]{3}{*}{0.079} \\
\hline & & Former & $1445(32.9)$ & $195(13.5)$ & \\
\hline & & Current & $2171(49.4)$ & $300(13.8)$ & \\
\hline & \multirow[t]{3}{*}{ Alcohol use } & Never or nearly never drinker & $929(21.2)$ & $150(16.1)$ & \multirow[t]{3}{*}{0.002} \\
\hline & & Moderate drinker & $2339(53.3)$ & $273(11.7)$ & \\
\hline & & High risk drinker & $1124(25.6)$ & $162(14.4)$ & \\
\hline & \multirow[t]{2}{*}{ Physical activity } & No & $3061(69.7)$ & $388(12.7)$ & \multirow[t]{2}{*}{0.107} \\
\hline & & Yes & $1331(30.3)$ & $197(14.8)$ & \\
\hline \multirow[t]{6}{*}{ Psychosocial factors } & \multirow[t]{2}{*}{ Feeling of depression } & No & $3991(90.9)$ & $479(12.0)$ & \multirow[t]{2}{*}{$<0.001$} \\
\hline & & Yes & $401(9.1)$ & $106(26.4)$ & \\
\hline & \multirow[t]{4}{*}{ Perceived level of stress } & Nearly none & $547(12.5)$ & $51(9.3)$ & \multirow[t]{4}{*}{$<0.001$} \\
\hline & & Low & $2583(58.8)$ & $290(11.2)$ & \\
\hline & & High & $1043(23.7)$ & $180(17.3)$ & \\
\hline & & Very high & $219(5.0)$ & $64(29.2)$ & \\
\hline \multirow{8}{*}{$\begin{array}{l}\text { Workplace environmental } \\
\text { factors }\end{array}$} & \multirow[t]{4}{*}{ Physical environment } & Very good & $855(19.5)$ & $85(9.9)$ & \multirow[t]{4}{*}{$<0.001$} \\
\hline & & Good & $1422(32.4)$ & $158(11.1)$ & \\
\hline & & Bad & $1303(29.7)$ & $186(14.3)$ & \\
\hline & & Very bad & $812(18.5)$ & $156(19.2)$ & \\
\hline & \multirow[t]{4}{*}{ Psychological environment } & Very good & $663(15.1)$ & $78(11.8)$ & \multirow[t]{4}{*}{$<0.001$} \\
\hline & & Good & $1737(39.5)$ & $193(11.1)$ & \\
\hline & & Bad & $1579(36.0)$ & $229(14.5)$ & \\
\hline & & Very bad & $413(9.4)$ & 85 (20.6) & \\
\hline
\end{tabular}

$P$ values were from from Cochran-Mantel-Haenszel chi square tests with adjustment for age

never or nearly never drinkers was highest in expert supervisors. Capitalists and small employers showed a greater prevalence of perceived stress and feeling of depression than other social classes. Nonskilled workers, nonskilled supervisors, and petty bourgeoisie reported worse physical workplace environment than did other social classes. All types of workers as well as nonskilled supervisors had worse psychosocial workplace environment than other groups. In women, petty bourgeoisie, nonskilled supervisors, and nonskilled workers had lower income than other classes, similar to those in men (Additional file 2: Table S2). The current smoking rate was highest in nonskilled supervisors in women. Petty bourgeoisie and nonskilled workers had a greater prevalence of worse physical work environment in women (Additional file 2: Table S2).

Table 4 shows the explanatory power of potential mediating variables in explaining the association between social classes and poor self-rated health. In models 2 to 5 including each potential mediating variable, the explanatory power of workplace environmental factors was highest in all social class positions except capitalists. The PR change due to workplace environmental factors in model 5 was about $31 \%$ in nonskilled workers and about $24 \%$ in skilled workers and nonskilled supervisors. Workplace environmental factors explained excess prevalence ratios in other classes by $11-19 \%$. The PR reduction with adjustment of material, behavioral, and 


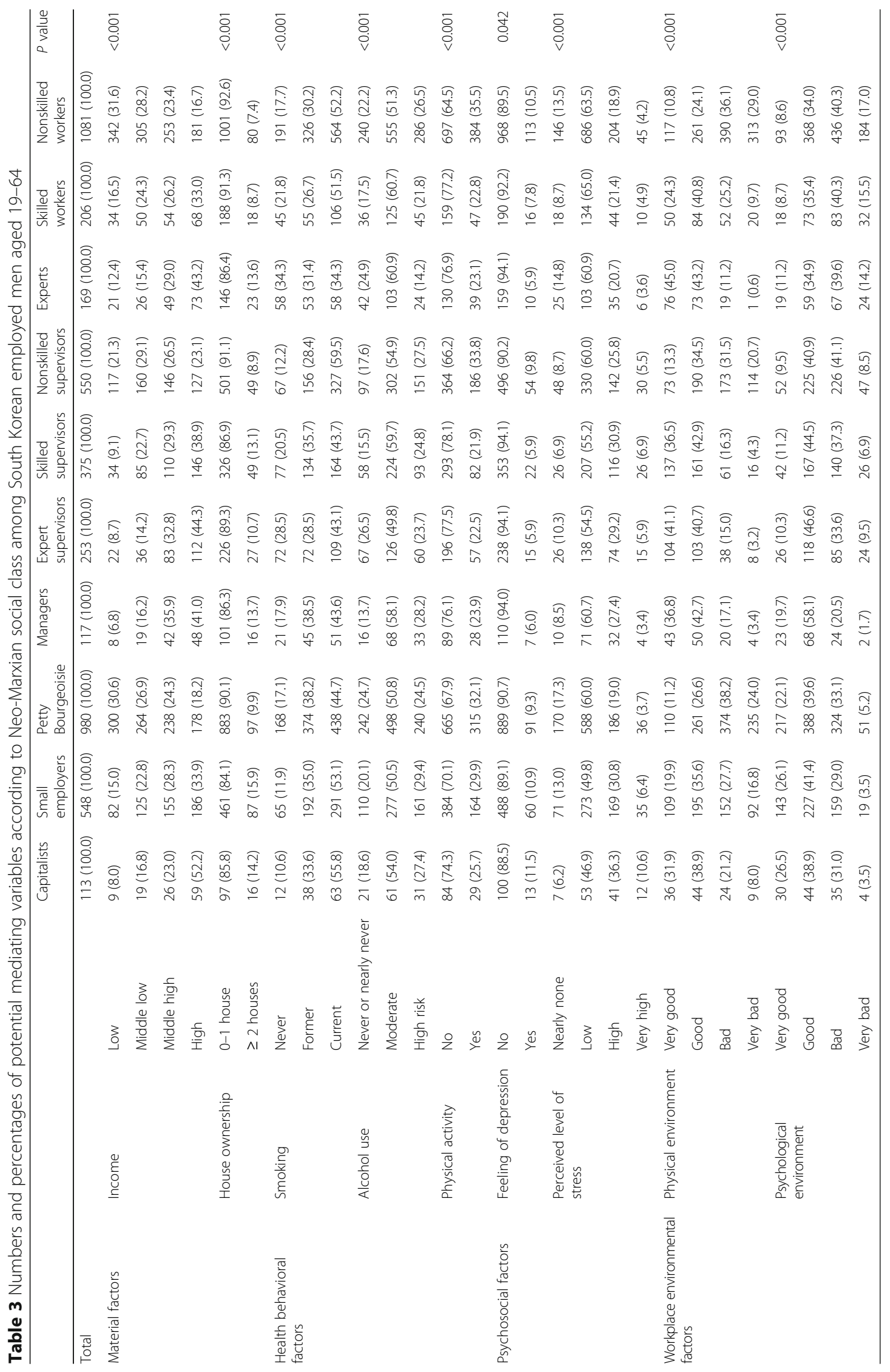




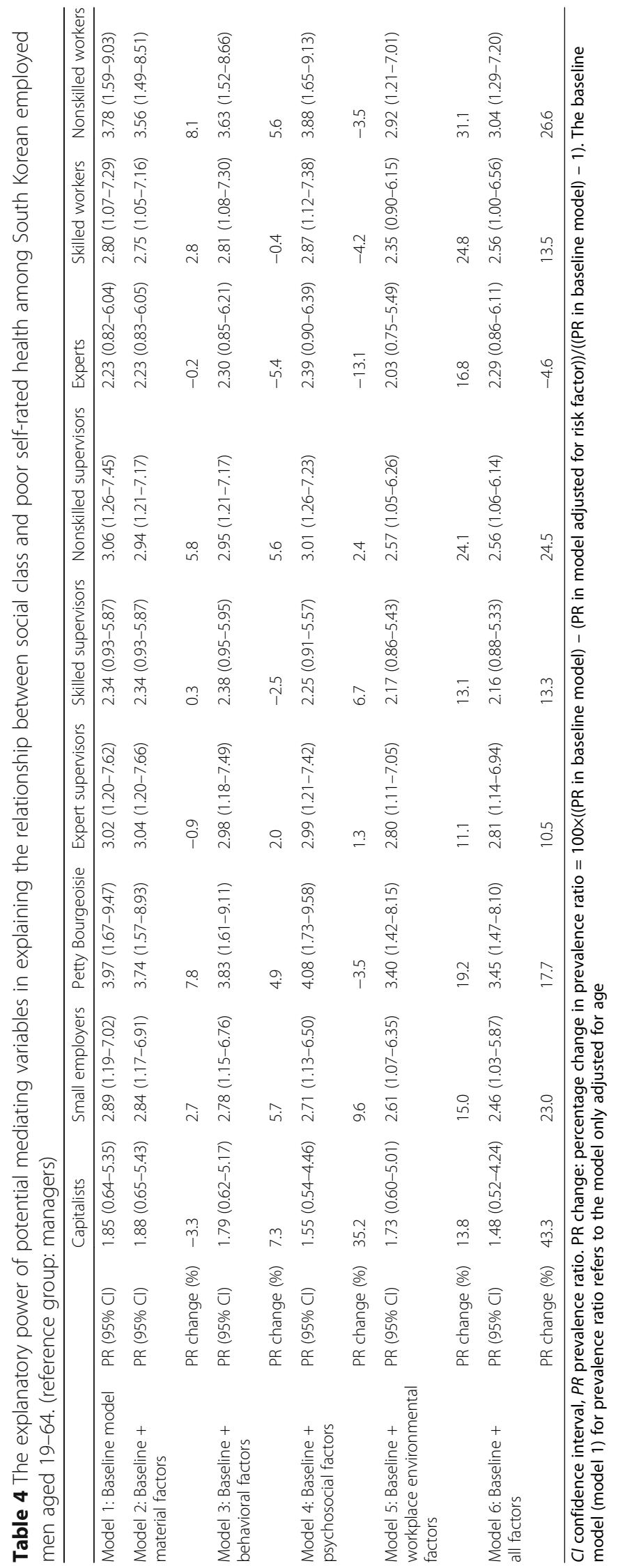


psychosocial factors mostly recorded less than $10 \%$. Material factors in model 2 explained the excess prevalence ratio in nonskilled workers by $8.1 \%$ and in petty bourgeoisie by $7.8 \%$. Behavioral factors in model 3 showed explanatory powers of about $5 \%$ in explaining the excess prevalence ratio in small employers, petty bourgeoisie, nonskilled supervisors and nonskilled workers. Introduction of psychosocial factors into model 4 lowered PR of small employers by $9.6 \%$. The adjustment of all potential mediating variables in model 6 showed an explanatory power of about $25 \%$ in nonskilled workers, nonskilled supervisors and small employers and only about $10 \%$ in expert supervisors.

\section{Discussion}

This study showed the inequality in poor self-rated health according to the Wright's social class in men. The risk of poor self-rated health was highest among petty bourgeoisie and nonskilled workers, which was modestly accounted for by workplace environmental factors and material factors.

The poor health status of petty bourgeoisie found in this study was somewhat different from the finding in a study of the city of Barcelona in which petty bourgeoisie's self-rated health was better than the supervisors [14]. The subjects of this study included individuals from rural areas as well as cities in South Korea. Petty bourgeoisie from rural areas accounted for $43.9 \%$ of total male petty bourgeoisie in this study. Our additional analyses showed that the indirectly standardized prevalence of poor self-rated health among rural petty bourgeoisie was $20.1 \%$ while the prevalence among urban petty bourgeoisie was $17.0 \%$. This result was similar to that of a previous study in which the self-employed in the agricultural sector reported much worse self-rated health than those in other social strata [36]. Korean economic development has been accomplished by focusing on industrialization and urbanization since the 1960s [37]. In this process, socioeconomic conditions in rural areas have worsened, and a higher mortality rate in rural areas than urban areas was reported [38].

The other reason of the worst self-rated health of petty bourgeoisie could be derived from the characteristic of the class itself and the change of its environment for survival. Petty bourgeoisie are free from the exploitation, however, at the same time, must use their own labor for an income unlike rentiers [12,39]. Given the increasing infiltration of capitals in conglomerates into the sectors of retail and food service in Korea, the economic environment has been more competitive for petty bourgeoisie than in the past [20]. It turned into their reducing income [20], and it could prevent the investment for the improvement of physical working environment and develop worse psychosocial working environment. In view of this, the result of this study that the workplace environmental factor was important for explaining the worse health status of petty bourgeoisie could be understood, and that was also consistent with a previous study [14].

Small employers had a worse perceived health status than managers, which was consistent with previous studies $[4,14]$. The intensified polarization between conglomerates and small-sized enterprises along with the high risk of bankruptcy in small-sized enterprises has been reported since the 1990s in Korea [40, 41]. The uncertain future of an owned small enterprise might have created an unfavorable perception about health among small employers. In a previous European study, small employers had a higher level of stress than employees [42]. Our analysis results also showed that the proportion of small employers with high level of perceived stress were relatively high (see Table 3 ).

The worst health status of nonskilled workers has been reported in other studies from Western countries [14, 15, 43-45]. This study adds an additional support for these prior findings in a relatively newly developed Asian capitalist country. The extent of explanation for the increased risk of poor health by workplace environmental factor (31\%) and material factor (8\%) was highest in nonskilled workers among social classes (see Table 4). As shown in Table 3, the 'very bad' physical and psychosocial working environments were concentrated on nonskilled workers who did not have any property, organizational, and skill assets. Moreover, almost $60 \%$ of nonskilled workers had a lower then median income in our data (Table 3). These findings suggest that nonskilled workers in South Korea were sharply experiencing exploitation through low income and uncontrollable working environment $[9,43]$.

Supervisors are one of the contradictory class positions $[12,46,47]$. The exploitation form capitalists with the insufficient authority over workers places supervisors between managers and workers and may subsequently impose worse psychological burden on them. Their general and mental health status was reportedly worse than experts or skilled workers in previous studies [14, 47]. Our study also provided evidence that expert supervisors and nonskilled supervisors might have worse self-rated health than expert workers and skilled workers as well as managers.

The study results suggest that the different level of skill assets seem to have different effects on perceived health among supervisors. The self-rated health of nonskilled supervisors tends to be better than that of workers with the same level of skill (nonskilled workers). Analysis results indicated that the psychosocial and physical working environment and income status of nonskilled supervisors tended to be better than nonskilled workers but worse than expert workers and 
skilled workers as well as other supervisors. Among nonskilled supervisors, relatively low organizational assets might have positively affected on perceived health through working environment and income, despite the adverse health impact of low skill assets. On the other hand, the prevalence of poor self-rated health of expert supervisors tended to be higher than expert workers with the same levels of skill. In other words, the social group with relatively low level organizational assets and high level skill assets was more likely to have worse perceived health status than the social group with no organizational assets and high level skill assets. Prior studies showed inconsistent findings on the relative health advantage of expert supervisors compared with other social groups $[4,15]$. A Spanish study showed that expert supervisors had better self-rated health and suggested that the skill assets might have played a crucial role in health status [4]. However, in a European study, expert supervisors reported worse mental well-being than non-expert supervisors, which was explained by the concept of 'status incongruence' [15, 48]. Expert supervisors could be considered as having high status congruence, because they had high skill assets and, at the same time, organizational assets. However, expert supervisors, as contradictory class location, could be controlled from the owner of productive assets, which might lead poor mental health. This concept of 'status incongruence' might be partly applied to our results. Future studies need to explore the interaction between organizational assets and skill assets and their effect on health.

Prior studies showed that the worst health status was found in nonskilled workers among social classes in women $[4,14,15]$. We also analyzed the differences in self-rated health by social class in women, but could not show a significantly increased risk of poor health among nonskilled female workers. The small sample size might have contributed to the finding. Furthermore, the labor market situation for South Korean women might have played a role in creating the weak social class inequality in poor self-rated health. A prior comparative study between Britain and Finland suggested the possibility that the women in a society with low employment participation rate and high rate of part time work might show a weak effect of their own occupational class and a strong effect of their household roles on health status [49]. In Korea, the average labor force participation rate of women aged 15-64 was only $54.7 \%$ [50] and about 70\% of women in the labor force were in nonstandard jobs in 2008 [51]. In addition, the average domestic work time of married and employed women was over 10 times greater than married and employed men [52], which might have created a 'dual burden' on employed women, affected women's poor self-rated health [14, 53, 54], and subsequently attenuated the magnitude of the effect of occupational class. It should be noted that, in most social classes, the self-rated health in women was poorer than that in women (Table 1). The pattern and mechanism of social inequality in health in South Korean women should be explored, considering both women's labor environment at workplace and power relations at homes.

Our findings should be interpreted in light of several limitations. First, we used a cross-sectional sample, so could not draw the causal direction of the relationships. Second, due to the restriction of secondary data, this study used only one point value of social class and potential mediating variables. This might have prevented from sufficiently revealing roles of Neo-Marxian social class on health and might have contributed to the relatively weak explanatory power of the potential mediating factors. Third, we could not have the sufficient sample size within each social class of twelve, so managers were analyzed as one group without differentiation of credential assets. However, this study showed social class inequality in self-rated health in a newly industrialized nonWestern capitalist country with nationally representative employed population including both employees and self-employed, which may contribute to the discussion about the socioeconomic inequality in health with the Neo-Marxist approach.

\section{Conclusions}

We identified the inequality in self-rated health according to the Wright's social class articulated by the ownership of the means of production, organizational assets, and skill assets at the point of production in an industrialized Asian country. The risk of poor self-rated health was highest among petty bourgeoisie and nonskilled workers, which was modestly accounted for by workplace environmental factors and material factors. Policy efforts to improve workplace environment in nonskilled and skilled workers and nonskilled supervisors would have a moderate effect on reducing the magnitude of social class inequality in self-rated health. Furthermore, the means to improve power relations in the workplace should be devised to further reduce the social class inequalities in health.

\section{Additional files}

Additional file 1: Table S1. The distribution of study subjects and the prevalence of poor-self-rated health according to potential mediating variables among South Korean employed women aged 19-64. (DOCX $40 \mathrm{~kb}$ )

Additional file 2: Table S2. Numbers and percentages of potential mediating variables according to Neo-Marxian social class among South Korean employed women aged 19-64. (DOCX 45 kb) 


\section{Abbreviations}

KNHANES: Korea National Health and Nutrition Examination Survey; KSCO: Korean Standard Classification of Occupation; PR: Prevalence ratio; SEP: Socioeconomic position

\section{Acknowledgements}

We thank all the participating employees and employers.

\section{Funding}

This work was supported by the Ewha Womans University Research Grant of 2012.

\section{Availability of data and materials}

All data were publicly available on the website of the Korea National Health and Nutrition Examination Survey (https://knhanes.cdc.go.kr/knhanes/ index.do).

\section{Authors' contributions}

KJC designed the study and collected the data. KAK performed the statistical analysis and drafted the manuscript. KAK, YHK, HJC, SMJ, and KJC critically revised the manuscript and approved the final paper. All authors read and approved the final manuscript.

\section{Competing interests}

The authors declare that they have no competing interests.

\section{Consent for publication}

Not applicable.

\section{Ethics approval and consent to participate}

The Institutional Review Board of the Ewha Womans University School of Medicine, Seoul, Korea, approved this study (EUMC 2015-01-001 [2015.01.29]). Consent to participate was not required, as this study did not involve human participant interactions and all data were publicly available and de-identified.

\section{Publisher's Note}

Springer Nature remains neutral with regard to jurisdictional claims in published maps and institutional affiliations.

\section{Author details}

${ }^{1}$ Department of Preventive Medicine, Ewha Womans University School of Medicine, Seoul, Korea. ${ }^{2}$ Department of Health Policy and Management and Institute of Health Policy and Management, Seoul National University College of Medicine, Seoul, Korea. ${ }^{3}$ Department of Family Medicine, Asan Medical Center, University of Ulsan College of Medicine, Seoul, Korea. ${ }^{4}$ Department of Occupational and Environmental Medicine, Ewha Womans University School of Medicine, Seoul, Korea.

\section{Received: 11 August 2016 Accepted: 13 April 2017}

\section{Published online: 20 April 2017}

\section{References}

1. Black D. The black report. In: Townsend P, Davidson N, editors. Inequalities in health. London: Penguin; 1990.

2. Marmot MG, Shipley MJ, Rose G. Inequalities in death-specific explanations of a general pattern? Lancet. 1984;1:1003-6.

3. Smith GD, Hart C, Blane D, Gillis C, Hawthorne V. Lifetime socioeconomic position and mortality: prospective observational study. BMJ. 1997;314:547-52.

4. Muntaner C, Borrell C, Benach J, Pasarin MI, Fernandez E. The associations of social class and social stratification with patterns of general and mental health in a Spanish population. Int J Epidemiol. 2003;32:950-8.

5. Kunst AE, Bos V, Lahelma E, Bartley M, Lissau I, Regidor E, et al. Trends in socioeconomic inequalities in self-assessed health in 10 European countries. Int J Epidemiol. 2005;34:295-305.

6. Commission on Social Determinants of Health. Closing the gap in a generation : health equity through action on the social determinants of health. Geneva: World Health Organization; 2008.

7. Chetty R, Stepner M, Abraham S, Lin S, Scuderi B, Turner N, et al. The association between income and life expectancy in the United States, 2001-2014. JAMA. 2016;315:1750-66.
8. Muntaner C, Borrell C, Vanroelen C, Chung H, Benach J, Kim IH, et al. Employment relations, social class and health: a review and analysis of conceptual and measurement alternatives. Soc Sci Med. 2010;71: 2130-40.

9. Muntaner C, Ng E, Chung H, Prins SJ. Two decades of Neo-Marxist class analysis and health inequalities: a critical reconstruction. Soc Theor Health. 2015;13:267-87.

10. Lynch J, Kaplan G. Socioeconomic position. In: Berkman LF, Kawachi I, editors. Social epidemiology. Oxford: Oxford University Press; 2000.

11. Navarro V. What we mean by social determinants of health. Int J Health Serv. 2009;39:423-41.

12. Wright EO. Class counts. Cambridge: Cambridge University Press; 1997.

13. Bartley M. Commentary: relating social structure and health. Int J Epidemiol. 2003;32:958-60.

14. Borrell C, Muntaner C, Benach J, Artazcoz L. Social class and self-reported health status among men and women: what is the role of work organisation, household material standards and household labour? Soc Sci Med. 2004:58:1869-87.

15. De Moortel D, Vandenheede H, Muntaner C, Vanroelen C. Structural and intermediary determinants of social inequalities in the mental wellbeing of European workers: a relational approach. BMC Public Health. 2014;14:938.

16. De Moortel D, Palencia L, Artazcoz L, Borrell C, Vanroelen C. Neo-Marxian social class inequalities in the mental well-being of employed men and women: the role of European welfare regimes. Soc Sci Med. 2015;128: $188-200$.

17. Kohn ML, Naoi A, Schoenbach C, Schooler C, Slomczynski KM. Position in the class structure and psychological functioning in the United States, Japan, and Poland. Am J Sociol. 1990;95:964-1008.

18. Hirokawa K, Tsutsumi A, Kayaba K. Occupation and plasma fibrinogen in Japanese male and female workers: the Jichi Medical school cohort study. Soc Sci Med. 2009;68:1091-7.

19. Cho DM. The change of the class structure of Korea, 1960-1990. Korean J Sociol. 1994;28:17-46.

20. Jang GY. The class structure of Korea in the neoliberal age. Marxism21. 2013 10:12-40

21. Van Oort FV, van Lenthe FJ, Mackenbach JP. Material, psychosocial, and behavioural factors in the explanation of educational inequalities in mortality in The Netherlands. J Epidemiol Community Health. 2005;59: 214-20.

22. Aldabe B, Anderson R, Lyly-Yrjanainen M, Parent-Thirion A, Vermeylen G, Kelleher CC, et al. Contribution of material, occupational, and psychosocial factors in the explanation of social inequalities in health in 28 countries in Europe. J Epidemiol Community Health. 2011;65:1123-31.

23. Stronks K, Van de Mheen H, Looman CWN, Mackenbach JP. Behavioural and structural factors in the explanation of socioeconomic inequalities in health: an empirical analysis. Sociol Health Illness. 1996;18:653-74.

24. Niedhammer I, Chastang JF, David S, Kelleher C. The contribution of occupational factors to social inequalities in health: findings from the national French SUMER survey. Soc Sci Med. 2008;67: 1870-81.

25. Kweon S, Kim Y, Jang MJ, Kim Y, Kim K, Choi S, et al. Data resource profile: the Korea National Health and Nutrition examination survey (KNHANES). Int J Epidemiol. 2014;43:69-77.

26. Borrell C, Muntaner C, Sola J, Artazcoz L, Puigpinos R, Benach J, et al. Immigration and self-reported health status by social class and gender: the importance of material deprivation, work organisation and household labour. J Epidemiol Community Health. 2008;62:e7.

27. Veenstra G. Neo-Marxist class position and socioeconomic status: distinct or complementary determinants of health? Crit Public Health. 2006;16:111-29.

28. Khang YH, Kim HR. Self-rated health and mortality: gender- and age-specific contributions of explanatory factors in South Korea. Int J Public Health. 2010;55:279-89.

29. Ohrr HC, Jee SH, Kim IS. Self rated health and mortality in elderly - Kangwha cohort, 8-year follow up. Korean J Epidemiol. 1994;16:172-80.

30. Richardson DB, Kinlaw AC, MacLehose RF, Cole SR. Standardized binomial models for risk or prevalence ratios and differences. Int J Epidemiol. 2015;44 1660-72.

31. Khang YH, Kim HR. Explaining socioeconomic inequality in mortality among South Koreans: an examination of multiple pathways in a nationally representative longitudinal study. Int J Epidemiol. 2005;34:630-7. 
32. Van Lenthe FJ, Gevers E, Joung IM, Bosma H, Mackenbach JP. Material and behavioral factors in the explanation of educational differences in incidence of acute myocardial infarction: the globe study. Ann Epidemiol. 2002;12: 535-42.

33. Daoud N, Soskolne V, Manor O. Educational inequalities in self-rated health within the Arab minority in Israel: explanatory factors. European J Public Health. 2009;19:477-83.

34. Mindell JS, Knott CS, Ng Fat LS, Roth MA, Manor O, Soskolne V, et al. Explanatory factors for health inequalities across different ethnic and gender groups: data from a national survey in England. J Epidemiol Community Health. 2014;68:1133-44.

35. VanderWeele T. Explanation in causal inference : methods for mediation and interaction. Oxford: Oxford University Press; 2015. p. 20-65.

36. Kim M, Chung W, Lim S, Yoon S, Lee J, Kim E, et al. Socioeconomic inequity in self-rated health status and contribution of health behavioral factors in Korea. J Prev Med Public Health. 2010;43:50-61.

37. Sung JK. A study on the direction of choosing developmental ideology concerning with the limitation of economic growth theory by industrialization. J Agr Sci. 1990;8:80-91.

38. Yoon $\mathrm{TH}, \mathrm{Kim} \mathrm{JH}$. Health inequalities between rural and urban areas in South Korea. J Korean Acad Rural Health Nurs. 2006;1:11-20.

39. Steinmetz $G$, Wright $E$. The fall and rise of the petty bourgeoisie: changing patterns of self-employment in the postwar United States. Am J Sociol. 1989;94:973-1018.

40. Hwang SW, Shin WY. The financial characteristics of income polarization and inequality in manufacturing industry. Korean J Business Admin. 2012;25: 741-65.

41. Wi PR. Growth and decline of Korean companies. Quart J Good Corporate Governance. 2013;47:36-55.

42. Benach J, Gimeno D, Benavides FG. Types of employment and health in the European Union. Luxembourg: Office for Official Publications of the European Communities; 2002.

43. Muntaner C, Borrell C, Sola J, Mari-Dell'olmo M, Chung H, Rodriguez-Sanz M, et al. Capitalists, managers, professionals and mortality: findings from the Barcelona social class and all cause mortality longitudinal study. Scand J Public Health. 2009;37:826-38.

44. Schrijvers CT, Van de Mheen HD, Stronks K, Mackenbach JP. Socioeconomic inequalities in health in the working population: the contribution of working conditions. Int J Epidemiol. 1998;27:1011-8.

45. Hammig O, Bauer GF. The social gradient in work and health: a crosssectional study exploring the relationship between working conditions and health inequalities. BMC Public Health. 2013;13:1170.

46. Wright E. Class boundaries in advanced capitalist societies. New Left Rev. 1976:98:3.

47. Muntaner C, Eaton WW, Diala C, Kessler RC, Sorlie PD. Social class, assets, organizational control and the prevalence of common groups of psychiatric disorders. Soc Sci Med. 1998;47:2043-53.

48. Lundberg J, Kristenson M, Starrin B. Status incongruence revisited: associations with shame and mental wellbeing. Sociol Health IIIn. 2009;31: 478-93.

49. Arber S, Lahelma E. Inequalities in women's and men's ill-health: Britain and Finland compared. Soc Sci Med. 1993;37:1055-68.

50. LFS by sex and age. 2009. http://stats.oecd.org/Index.aspx?DataSetCode= STLABOUR. Accessed 16 Sep 2009.

51. Kim YS. The size and conditions of the workforce in irregular employment. In: Kim YS, editor. Labour society bulletin 144. Seoul: Korea Labour \& Society Institute; 2009.

52. Kim JW. An empirical study on the dual burden of married working women: testifying the adaptive partnership, dual burden and lagged adaptation hypotheses. Korean J Soc Welfare. 2005;57:51-72.

53. You SY. A study of the health status of a husband and wife related to paid and unpaid work and family characteristics for the dual-earner household with respect to job satisfaction and reciprocity. Korean Soc Community Living Sci. 2008;19:509-18.

54. Hall EM. Double exposure: the combined impact of the home and work environments on psychosomatic strain in Swedish women and men. Int J Health Serv. 1992;22:239-60.

\section{Submit your next manuscript to BioMed Central and we will help you at every step:}

- We accept pre-submission inquiries

- Our selector tool helps you to find the most relevant journal

- We provide round the clock customer support

- Convenient online submission

- Thorough peer review

- Inclusion in PubMed and all major indexing services

- Maximum visibility for your research

Submit your manuscript at www.biomedcentral.com/submit 